\title{
Proteinuria is an equivalent marker for low renal function
}

\author{
Antonio Miceli, MD, PhD
}

See related article on pages 894-9.

Acute kidney injury (AKI) occurs in 3\% to $30 \%$ of patients undergoing cardiac surgery and is associated with increased mortality, morbidity, prolonged hospital stay, and increased health care costs. In the last years, several risk models have been developed to identify potential risk factors for postoperative AKI, and among these preoperative renal function has been considered one of the most important predictor of adverse outcomes. ${ }^{1}$ The identification of new risk factors represents a step forward toward a better risk stratification that can help optimize therapeutic strategies for the prevention of AKI and its consequences. Recently, proteinuria has been recognized as a powerful measure of kidney disease, providing relevant prognostic information for postoperative AKI in addition to estimated glomerular filtration rate (eGFR). ${ }^{2}$

In this issue of the Journal, Li and colleagues ${ }^{3}$ add evidence that any grade of preoperative proteinuria detected with a urine dipstick test is strongly associated with all stages of postoperative AKI among patients with preserved eGFR. They report a study cohort of approximately 1200 patients with preserved eGFR $\left(80 \pm 13 \mathrm{~mL} / \mathrm{min} / 1.73 \mathrm{~m}^{2}\right)$ who underwent cardiac surgery from 2003 to 2007. AKI was defined according to Acute Kidney Injury Network criteria, and proteinuria was graded $1+(30-100 \mathrm{mg} / \mathrm{dL})$, $2+(100-300 \mathrm{mg} / \mathrm{dL})$ and $3+(>300 \mathrm{mg} / \mathrm{dL})$. Interestingly, among patients undergoing surgery, proteinuria was present in $23.4 \%$, and $50 \%$ of these had AKI develop. After adjustment for baseline characteristics and eGFR, patients with proteinuria $1+, 2+$, and $3+$ had mean of 4-, 9-, and 9-fold increased risks of postoperative AKI, respectively. The report of $\mathrm{Li}$ and colleagues, ${ }^{3}$ which relies on large patients numbers, gives an important message: even in the presence of a normal eGFR measurement, one-fourth of patients are still at risk, and the probability of AKI development increases with increasing severity of proteinuria. The use of the urine dipstick, a simple, cheap and

From the School of Clinical Science, University of Bristol, Bristol, UK and the Department of Cardiac Surgery, Istituto Clinico Sant'Ambrogio, Milan, Italy.

Disclosures: Author has nothing to disclose with regard to commercial support.

Received for publication Oct 23, 2014; accepted for publication Oct 25, 2014; available ahead of print Dec 3, 2014.

Address for reprints: Antonio Miceli, MD, PhD, School of Clinical Science, University of Bristol, Bristol, BS2 8HW UK (E-mail: antoniomiceli79@alice.it).

J Thorac Cardiovasc Surg 2015;149:900-1

$0022-5223 / \$ 36.00$

Copyright (c) 2015 by The American Association for Thoracic Surgery

http://dx.doi.org/10.1016/j.jtcvs.2014.10.108 widely available diagnostic test, may identify and unmask a consistent group of patients otherwise considered "normal" from a renal point of view. Potential limitations, however, should be recognized.

From a pathophysiologic point of view, the presence of protein in the urine reflects a size-selective dysfunction of the glomerular barrier or tubulointerstitial disorder and is often associated with hypertension, diabetes, or glomerulopathy. In this setting, patients with documented proteinuria have less physiologic adaptability and are less able to tolerate kidney hemodynamic changes and other nephrotoxic insults. $^{2}$ AKI is a multifactorial disease and depends on many preoperative, intraoperative and postoperative variables. Risk factors such as hypertension, preoperative medications, previous heart surgery, perioperative myocardial infarction, endocarditis, cardiogenic shock, prolonged cardiopulmonary bypass, intraoperative hypotension, and hemodilution are well-known predictors of worse renal outcomes; however, none of these variables were taken into account in a multivariable analysis. ${ }^{1}$ In addition, no information is reported regarding the temporal relationship between coronary angiography and the timing of cardiac surgery. It has been suggested that a "double hit" on renal function in close succession increases the risk of AKI after cardiac surgery. ${ }^{4}$ Finally, although the study was performed on patients with preserved renal function (eGFR $>60 \mathrm{~mL} / \mathrm{min} /$ $1.73 \mathrm{~m}^{2}$ ), $77 \%$ of them had mild renal dysfunction, with an eGFR between 60 and $90 \mathrm{~mL} / \mathrm{min} / 1.73 \mathrm{~m}^{2}$. It is well known that a mild degree of renal dysfunction is an important predictor of AKI and others adverse outcomes in cardiac surgery. ${ }^{5}$

For the surgical community, the results of this study represent another important advance in the evaluation of perioperative risk stratification for renal outcomes and complications. An accurate assessment of proteinuria in the presence of preserved renal function might distinguish patients with occult renal disease at risk for AKI and provide a better risk stratification that can help to optimize therapeutic strategies for the prevention of AKI, just as for patients with low eGFR.

\footnotetext{
References

1. Huen S, Parikh CR. Predicting ACUTE kidney injury after cardiac surgery: a systematic review. Ann Thorac Surg. 2012;93:337-47.

2. Coca SG, Jammalamadaka D, Sint K, Thiesen Philbrook H, Shlipak MG, Zappiteli M, et al. Preoperative proteinuria predicts acute kidney injury in patients undergoing cardiac surgery. J Thorac Cardiovasc Surg. 2012;143: 495-502.

3. Li SY, Chuang CL, Yang WC, Shing-Jong L. Proteinuria predicts postcardiotomy acute kidney injury in patients with preserved glomerular filtration rate. $J$ Thorac Cardiovasc Surg. 2015;149:894-9.
} 
4. Medalion B, Cohen H, Assali A, Vaknin Assa H, Farkash A, Snir E, et al. the effect of cardiac angiography timing, contrast media dose, and preoperative renal function on acute renal failure after coronary artery bypass grafting. J Thorac Cardiovasc Surg. 2010;139:1539-44.
5. Cooper WA, O'Brien SM, Thourani VH, Guyton RA, Bridges CR, Szczech LA et al. Impact of renal dysfunction on outcomes of coronary artery bypass surgery: results from the Society of Thoracic Surgeons National Adult Cardiac Database. Circulation. 2006;113:1063-70.

Access to The Journal of Thoracic and Cardiovascular Surgery Online is reserved for print subscribers!

Full-text access to The Journal of Thoracic and Cardiovascular Surgery Online is available for all print subscribers. To activate your individual online subscription, please visit The Journal of Thoracic and Cardiovascular Surgery Online, point your browser to http://www.mosby.com/itcvs, follow the prompts to activate your online access, and follow the instructions. To activate your account, you will need your subscriber account number, which you can find on your mailing label (note: the number of digits in your subscriber account number varies from 6 to 10). See the example below in which the subscriber account number has been circled:

\section{Sample mailing label}

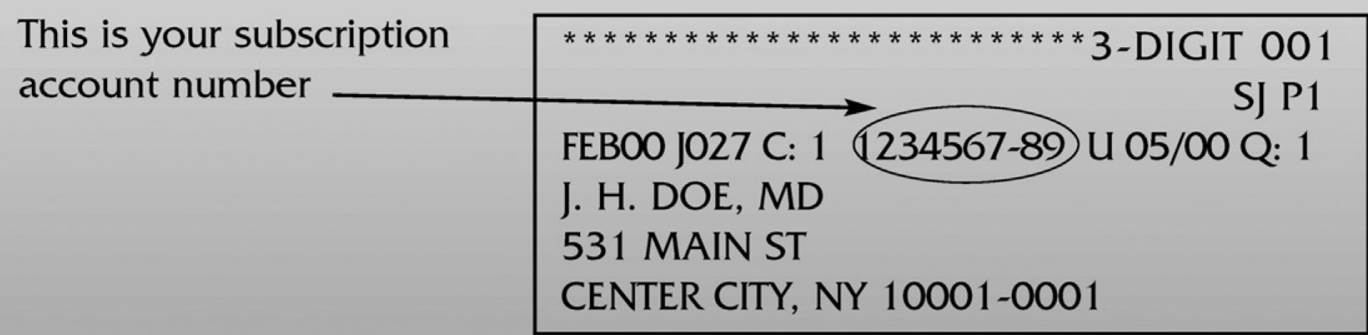

Personal subscriptions to The Journal of Thoracic and Cardiovascular Surgery Online are for individual use only and may not be transferred. Use of The Journal of Thoracic and Cardiovascular Surgery Online is subject to agreement to the terms and conditions as indicated online. 